\title{
RELATIONSHIP BETWEEN AGENCY COSTS AND FINANCIAL PERFORMANCE OF MICRO-FINANCE INSTITUTIONS IN MACHAKOS COUNTY
}

\author{
Nzau Ndeto \\ Master of Business Administration (MBA) \\ St. Paul's University, Kenya
}

\section{ABSTRACT}

Undeniably, agency cost has emerged as one of the leading determinants of financial performance of a firm. The purpose of this dissertation was to conduct an assessment into the relationship between agency costs and financial performance of Micro-Finance Institutions (MFIs) in Machakos County, Kenya. Specifically, the study sought to investigate the influence of monitoring costs, bonding costs and residual loss on financial performance of microfinance institutions in Machakos County in, Kenya. In order to achieve these objectives, a descriptive design was used. The target population of the study comprised the three MFIs in the Machakos County. To obtain primary data on agency costs, 5- point Likert scale structured questionnaires were ministered to blockholders, finance directors and chief executive officers who were selected through census technique. Secondary data was extracted from the annual reports of the MFIs to determine financial performance. Descriptive statistics such as the mean and standard deviations while inferential statistics included correlation and regression procedures were used to analyze the data. The study found out a significant relationship between monitoring costs and financial performance. Also established was that bonding costs were found to significantly influence financial performance. The study equally established a strong positive correlation between the residual loss and financial performance. The
\end{abstract}

findings were presented using frequency tables. The study recommends that an indepth investigation should be done on competitive challenges facing the microfinance firms in Machakos county and Kenya in general. Kenya has come of age against the backdrop increased development of mobile phone-based lending platforms which have seriously affected the financial performance of micro finance institutions. The study also recommends that the influence of moderating and intervening factors such as age and size of the firm should be examined, since that was not within the scope of the current study, and more so because the study has adduced mixed results, probably due to the influence of control variables that were not modelled in the study.

\section{INTRODUCTION}

An agency relationship occurs when a principal hires an agent to perform certain duties on his/her behalf. A conflict known as agency problem arises because of the divergent interest between the needs of the principal and those of the agent. This problem leads to certain expenses from both antagonistic parties. Agency costs arise as a result of conflict of interest between shareholders and the company's managers. A shareholder in the normal operations of the organizations activities wants the manager to make decisions which will increase the shareholders value. However, managers instead would prefer to expand the business and increase 
their earnings, which may not necessarily increase shareholders value.

Originally, agency problem was raised by Jensen and Meckling (1976) who stated that, lack of consistent interest in the needs of shareholders and management leads to agency costs. Indeed, separation of management and ownership does not come without costs. Alabdullah (2016) argued that lack of complete contractual relationship between the needs of the agent and the principal might cause agency problem. Further, Nobanee, Ellil and Abraham (2017) stated that performance can be defined as end results and achievement, positive or negative outcome of an activity carried out by an organization.

Agency costs is the cumulative of three types of costs that characterize agent operations or functionality which include monitoring costs, bonding costs and residual loss. Costs of monitoring are those spent on making follow-up or evaluating all the management processes or activities the agent carries out in the company on behalf of the owners. Generally, such compensation or payment made for monitoring, remunerating and assessing the performance of the agent or manager who runs the company constitute agency costs. Equally, agency costs include those that compensate the board of directors, expenses spent to hire, develop as well as train staff.

On the hand, costs being referred to as bonding are incurred by the managers or agents in discharging contractual responsibilities or mandate to impress their bosses (principals). Such costs are incurred to carry out their roles meant to ensure the owners achieve their desired goals. Usually, bonding expenses are utilized to establish and function according to a definite structure or system. The two types of costs discussed above take divergent direction in that increased bonding costs should lead to decrease in monitoring costs.

The conflict of interest between the shareholders and managers results in another problem, where the decision taken by the managers are not aligned to maximize the wealth of the owners. These inefficient managerial decisions lead to a loss known as the residual loss. Alabdullah (2016) elucidated that the residual loss is the key component of the agency cost, which should have to be reduced by the principals. To reduce the residual loss, the owners incur monitoring cost and bonding cost. Hence, these costs have become the whole of the irreducible agency cost.

Financial performance can be measured using different ways of which all should be taken in aggregation. Items such as operating income, revenue from operations and cash flow from operations can be used as total unit sales. Ratios such as return on investment (ROI), return on assets (ROA) and return on equity (ROE) can be used by the financial analyst to seek out declining debt or marginal growth rate of the firm.

\section{Problem Statement}

Despite the importance placed on MFIs, available empirical literature consists of solid an undesirable connection between agency costs and financial performance of MFIs in Kenya (Mukulu, Rukaria \& Sakwa, 2015). However, agency costs have negatively impacted MFIs such as lowering the market value, ROA, ROI, ROE and return on capital. For instance, the CBK annual report of the year ending 2017 , painted a grey picture of a $10 \%, 8 \%$ and $11 \%$ declining return on asset, return on investment and return on equity respectively among the MFIs branches in Machakos County (CBK, 2017).

Despite the negative performance associated with agency costs in microfinance institutions, there seems to be scarcity of research in this field. To that end, most of these studies are contextually based abroad especially the developed countries. Besides, not much research has been done to establish how agency costs are related to the performance of finances specifically for Microfinance Banks in Machakos County in Kenya. In order to fill this gap, the current study sought to find out the relationship between agency costs and financial performance MFIs in order to act as a guide to microfinance stakeholders in controlling agency costs as they pursue good financial performance for institutions they manage.

\section{LITERATURE REVIEW}

Quayes (2015) advises MFIs to embrace audit as an additional strategy of monitoring agents. The author asserts that mechanisms such as auditing, 
authenticates or validates operations and decisions of the affiliates are in tandem with interests and aspirations of the shareholders. Ahmed, Bhuiyan, Ibrahim, Said and Salleh (2016), in their work in Malasya, assert that firms from overseas record higher agency related costs due to policy of these firms to employ highly qualified to do best auditing because the principals are far.

This view is shared by Bortych's (2017) findings in a research conducted in the USA which established that MFIs hire high-end quality auditing officers. Studies reveal MFIs operating in many countries, release more detailed financial reports than firms that operate exclusively in a single country. Understandably, reports with more details emanate from more aspects or items to be audited requiring more auditing input in terms of time and human effort. As a result, auditors charge more fees for such massive work culminating in increased agency costs.

According to agency theory, structure of ownership contributes significantly to reduced agency costs. Conventionally, agency costs can decrease by increased number of firm owners being part of the board of directors. The argument is that more directors on the board of directors increase monitoring chances. Similarly, D'Espallier, Goedecke, Hudon and Mersland (2017) revealed zero agency cost among companies where the owner doubles as the manager because this structure ensures the alignment of both the owners and managers' interests. This is because employees receive dividends from company increased returns.

Residual loss is a category of agency cost that originated from principal and agent theory in the 1970s from the combined disciplines of economics and institutional theory. Theorist Stephen Ross is credited to have originally come up with the idea and later developed by Barry Mitnick. However, the most cited reference to the theory comes from Michael Jensen and William Meckling (1976) who asserted that Residual loss are costs emanating from divergent principal and agent interests despite the use of monitoring and bonding.

Additionally, Kleynjans and Hudon (2016) carried out a study among 505 companies at the
Taiwan Stock Exchange (TSE) between 2013 and 2014 on the relationship between free cash flow and agency costs. Performance of a company was operationalized as ROA and ROE. The findings showed a strong positive correlation between the ratio of asset turn over and performance of a firm in terms of ROA and ROE. Also, operating expenses to sales ratio were found to influence company performance operationalized as ROA and ROE.

\section{METHODOLOGY}

This study adopted descriptive research design. For this study, the target population was the three MFIs in Machakos county. Although there might have been more MFIs, only three (3) microfinance institutions which included Faulu Microfinance Bank Ltd, Kenya Women Microfinance Bank Ltd and SMEP Microfinance Bank Ltd (CBK, 2017) qualified to for consideration.

The accessible population compromised 19 block-holders, 15 board of directors, 2 CEOs and 3 finance directors from all microfinance institutions in Machakos county. This study used primary data (questionnaires) and secondary data. A multiple correlation and regression analysis was used. This helped to determine the relationship between agency cost and financial performance of micro-finance institutions in Machakos County.

\section{RESULTS}

The study determined that $24.8 \%$ change in financial performance could be attributed to change in monitoring costs. It is also evident from the findings above that there was a medium negative correlation between the variables as shown by -0.498 . The regression model had a fit with the data $(\mathrm{F}=3.814, \mathrm{P}<0.05)$. This is an indication that monitoring costs had a significant influence on financial performance at 5\% level of significance since the p-value was $0.1 \%$, which was below $5 \%$.

It was determined that if there were no changes in bonding costs, the finacial performance score would be at 1.445 . However, a unit change in bonding costs led to increase in financial performance by a factor of 0.421 . At $5 \%$ level of significance, bonding costs were found to 
significantly influence financial performance. The significance level for the beta factor was $0.2 \%$ which was below the $5 \%$ threshold.

It was found that the value of adjusted $\mathrm{R}$ squared was 0.724 . This shows that there was a change of $72.4 \%$ on financial performance as a result of variations in residual loss. Therefore, at $5 \%$ level of significance, $72.4 \%$ change in financial performance was explained by change in residual loss. The value of $\mathrm{R}$ was 0.881 , implying a strong positive correlation between the residual loss and financial performance.

\section{RECOMMENDATIONS}

The study recommends that the academics in the field of strategic management should consider using the empirical evidence adduced to further their research interests. Theorists should also consider the findings of this study to find further empirical foundation in light of the linkages between corporate governance, ownership structure, and organizational performance.

The study further recommends the findings for the development of policies that would be geared towards sustainability of the microfinance firms in Kenya. The Ministry of Finance and other relevant government agencies in Kenya should apply the study findings in decision making since it would assist in developing well-informed policies geared towards the achievement of the Vision 2030, the Big Four agenda, and the sustainable development goals in Kenya.

Finally, the study recommends that the top management team of the respective microfinance institutions in the survey should use the findings for guidance and planning in making necessary reforms to their respective MFIs to enhance their positive financial performance for the benefit of the shareholders returns. Specifically, because the study findings has drawn important lessons for success and best practices for the microfinance sector, sustainability against the backdrop of increased competition from the mobile telephone based electronic lending platforms such as Tala, Fuliza among others in Kenya.

\section{REFERENCES}

1. Ahmed, I., Bhuiyan, A. B., Ibrahim, Y., Said, J., \& Salleh, M. F. M. (2016). Social Accountability of Microfinance Institutions in South Asian Region. International Journal of Economics and Financial Issues, 6(3), 824-829.

2. Alabdullah (2016). Agency cost and management behavThe: The role of performance as a moderator. Journal Finance, 5, 1.

3. Kleynjans, L., \& Hudon, M. (2016). A study of codes of ethics for Mexican microfinance institutions. Journal of Business Ethics, 134(3), 397-412.

4. Mukulu, E. Rukaria, G., \& Sakwa, M. (2015). Challenges affecting transformation of microfinance institutions into deposit taking financial institutions in Kenya. Journal of Scientific and Research Publications.

5. Quayes, S. (2015). Outreach and performance of microfinance institutions: A panel analysis. Applied Economics, 47, 1909-1925 